HABITAT, 28 (1), 2017, 1-6

DOI: 10.21776/ub.habitat.2017.028.1.1

\title{
Technical Efficiency Analysis of Mini Purse Seine Fishing Unit in Sumenep District
}

\author{
Mohammad Ibrahim Fatoni ${ }^{{ }^{*}}$, Nuhfil Hanani ${ }^{2}$, Suhartini ${ }^{2}$ \\ ${ }^{1}$ Master of Agricultural Economics, Faculty of Agriculture, University of Brawijaya \\ ${ }^{2}$ Department of Social Economics, Faculty of Agriculture, University of Brawijaya, Jl. Veteran Malang \\ 65145, Jawa Timur, Indonesia
}

Received: 13 January 2017; Revised: 24 February 2017; Accepted: 27 February 2017

\begin{abstract}
The nature of competition in each purse seine fishing unit leads to excess fishing capacity utilization. This study aimed to analyze factors affecting fishing capacity in the short term, knowing the level of efficiency at each purse seine fishing unit, and to analyze factors affecting technical inefficiency. This study was conducted in Sumenep, East Java. The method used was parametric inferential statistics. The method of nalysis in this study was SFA (Stochastic Frontier Analysis) and tobit model. The research results show that number of trip, amount of FADs used, and the number of crew operator operating purse seine are significant factors affecting fishing capacity, average level of technical efficiency's of fishing unit is $36 \%$, and the factors that negatively influence the technical inefficiency is experience of captain and the status of ownership of the vessel while the the factors that positively influence is age of captain.
\end{abstract}

Keywords: stochastic frontier analysis; tobit

How to cite:

Fatoni, M. I., Hanani, N., \& Suhartini, S. (2017). Technical Efficiency Analysis of Mini Purse Seine Fishing Unit in Sumenep District. HABITAT, 28(1), 1-6. https://doi.org/10.21776/ub.habitat.2017.028.1.1

\section{Introduction}

Estimates of fishery potential of small pelagic fish that have been over fishing in the Java Sea makes two of the three types of active fishing gears i.e. seine nets and trawls be prohibited nationally (Minister of Marine Affairs and Fisheries, 2015). The regulation makes purse seine into the only one active gear collectively catching fish to permitted to operate (Kefi et al., 2013). This makes the production of purse seine to be strategic to support environmental sustainability and economic development for the fisheries sector. Sumenep is the center of purse seine utilization in East Java Province based on the number of units of purse seine and trips done (The Department of Marine Affairs and Fisheries East Java, 2014). Purse seines in the district are classified as small purse seine operated using vessels below 20 GT with the operating system of one-day trip (Utomo et al., 2013). One-day trip system is applied because the fishing grounds are still close. It shows that the waters in Sumenep

${ }^{*}$ Corresponding Author.

E-mail : rbmibrahimfatoni@gmail.com

Telp : + 62-813-33100667
District, which is the only district in East Java whose form is island, is still a fertile area despite being in the Java Sea.

However, the high number of purse seine units and trips, as well as fertility and resource, do not make this district rank first in terms of total catches of purse seines (The Department of Marine Affairs and Fisheries East Java, 2014); this shows overcapacity of capture fisheries used. The capacity of short-term capture fisheries is the power that comes from a combination of capture fisheries inputs used in normal conditions but is not restricted to exploit fish stocks (Pascoe, 2003). The use of excessive inputs on every fishing unit would encourage excess capacity in utilizing fisheries resources. It can also indicate the inability of fishermen to use inputs of capture fisheries so that they can produce a level of catches in accordance with the capacity formed from by the inputs.

Technical efficiency in capture fisheries can be defined as the use of excessive fishing capacity to obtain the level of catches (output). Analysis of excess fishing capacity through technical efficiency approach has been made by researchers in the world using Stochastic (SFA) (Jamnia et al., 2013) and Deterministic Approach 
(DEA) (Rahman et al., 2016). Both approaches have drawbacks and advantages (Coelli et al., 2005). Because of the many external variables that influence the success of fishing operations, the SFA approach that separates the effects of inefficiencies and the effect of the error is considered more suitable to analyze the technical efficiency of capture fisheries (Tingley et al., 2005).

To set the fishing capacity using small purse seine units in Sumenep requires information on the technical efficiency of the units as well as the factors that influence the capacity and technical efficiency. Lack of research on technical efficiency of purse seine units in Sumenep makes the present policies have no real impact. Vessels with a capacity of 30 GT have become inactive because fishermen consider their use detrimental. Therefore, the study on the efficiency of input use technically on each small purse seine unit needs to be done.

\section{Research Method}

\subsection{Data Collection Method}

The sampling method used was purposive sampling at for Fishing Port Installation (FPI) as a fishing base and random sampling on the selection of the captain. Pasongsongan Fishing Port Installation was selected as the sample area as it has a complete data center for the use of purse seine units in Sumenep. The captain status becomes important, as the captain is the leader of the group that not only determines the fishing ground, but also decides whether fishing must be done or not in a certain fishing ground.

Sample size is determined based on Slovin formula (Boesono et al., 2015) with a confidence level of 0.1 . The confidence level is chosen with consideration of the characteristics that tend to be homogeneous i.e. using small purse seine units. Of a total population of 326 , then a sample size of 77 captains rounded to 80 captains was obtained. Secondary data in this study was obtained from information collected by the Pasongsongan Fishing Port including the data on catches during the eastern season in 2015, the data on gross tonnage of the ship, and the data on the number of trips per vessel. While primary data was collected through interviews including the number of people required for the capture, length of purse seine, the number of FADs, age of the captains, experience of the captains, formal education of the captains, and ship ownership status.

\subsection{Method of Analysis}

\subsubsection{Specification on Production Model}

In the economy perspective related to production, the use of excess capacity is technical inefficiency (Pascoe, 2003). To test for the presence and levels of technical inefficiency, Stochastic Frontier Analysis (Coelli et al., 2005) was used in this study. The following is the model specification of the stochastic production function used:

$Y_{i}=\alpha \prod_{n=1}^{5} X_{n i}^{\beta_{n}} e^{(v-u)_{i}}$

In which:

$Y \quad=$ aggregation of capture per vessel $(\mathrm{kg})$

$\mathrm{X}_{1 \mathrm{i}}=$ number of trips

$\mathrm{X}_{2 \mathrm{i}}=$ vessel volumetrick (GT)

$\mathrm{X}_{3 \mathrm{i}}=$ length of purse seine $(\mathrm{m})$

$\mathrm{X}_{4 \mathrm{i}}=$ number of FADs

$\mathrm{X}_{5 \mathrm{i}}=$ number of crews operating purse seine

$v=$ random error

$u=$ inefficiency effect

$\alpha, \beta=$ estimated parameter

$i=$ sample of vessel unit number- $\mathrm{i}$

Measurement on the technical efficiency toward the stochastic production function can be mathematically defined as follows:

$\mathrm{EFF}=\frac{\mathrm{E}\left(\mathrm{Y}_{\mathrm{i}}^{*} \mid \mathrm{U}_{\mathrm{i}}, \mathrm{X}_{\mathrm{i}}\right)}{\mathrm{E}\left(\mathrm{Y}_{\mathrm{i}}^{*} \mid \mathrm{U}_{\mathrm{i}}=0, \mathrm{X}_{\mathrm{i}}\right)}$.

Thus, efficiency level will be in the range of 0 and 1 (Coelli et al., 2005).

The parameter value of production factors and the level of technical efficiency was obtained by regression using the maximum likelihood method. FRONTIER 4.1 program is used in the process of regression (Coelli, 1996).

\subsubsection{Specifications of Inefficiency Model}

Tobit Model is used for regression of factors affecting inefficiency. Tobit Model is a regression model that describes the bound input and free input where the bound input has mixed or limited scale (threshold) (Otieno et al., 2014). Inefficiency value itself has a threshold that cannot be less than 0 and cannot be more than 1 .

Inefficiency has a function of $m_{i}=\delta_{0}+$ $z_{i} \delta_{i}$ in which $m_{i}$ is the inefficiency level, $z_{i}$ is assumed as variable affecting inefficiency, and $\delta_{i}$ is the parameter to be estimated (Battese and Coelli, 1995). Then the technical inefficiency function in this study is as follows:

$m_{i}=\delta_{0}+\sum_{n=1}^{4} z_{n i} \delta_{n}+w_{i}$ 
In which:

$\begin{array}{ll}\mathrm{z}_{\mathrm{i} 1} & =\text { age (in year) } \\ \mathrm{z}_{2 \mathrm{i}} & =\text { education (in year) } \\ \mathrm{z}_{3 \mathrm{i}} & =\text { experience (in year) } \\ \mathrm{z}_{4 \mathrm{i}} & =\text { ship ownership } \\ w_{i} & =\text { random error } \\ \delta & =\text { estimated parameter } \\ i & =\text { sample of purse seine unit number } \mathrm{i}\end{array}$

\section{Results and Discussion}

\subsection{Characteristics of Purse Seine Units}

The vessels in the study site normally have a volume of $14.55 \mathrm{GT}$, with an average volume of 12 GT to 18 GT. They use Mitsubishi motor PS 120 with a speed power of 60 HP (Horse Power). The purse seine units used have a length of 350 meters and 370 meters, and a width of 70 meters. It takes around 17 to 23 fishermen, in average of 20 fishermen, to operate the unit per vessel.

The purse seine units in Pasongsongan Fishing Port operate with the system of one-day trip without the use of ice. The departure schedule for fishing activities usually is between 13.00 to $16.00 \mathrm{PM}$, while the schedule of arrival is between 05:30 until 10:00 AM the next morning.

East monsoon (wind blowing from the east) is a good season for fishing because the waves are relatively calm and stable than the west monsoon (wind blowing from the west). East monsoon occurs from July to December with the peak season (the highest amount of fish in the fishing ground) from August to November. Capture at the peak season on average is performed at a distance of 30 miles from the fishing base. Fuel needed during the peak season in one trip on average is 240 liters and FADs deployed on average per unit as much as 12 FADs at a distance of over 12 miles from the fishing base. During the east monsoon, there are more ships active than during the west monsoon because the sea waves are relatively calm.

Purse seine fishing operations in the sample area have no specific fish, as the target so that all the fish is collected on FADs will be taken. The type of fish caught in the east season include giant catfish, flying fish, sardine, tuna, dolphin, banyar, mackerel, mackerel, pomfret fish, semar, squid, mackerel scad, barracuda, red snapper fish, sunglir, sword fish, swangi, shark, peperek, remang, daun bambu, and terumbuk. Type of fish caught most is the flying fish.
Table 1. Characteristics of the Ship Captains

\begin{tabular}{|c|c|}
\hline Attribute & Average \\
\hline Age (in year) & $43(23-62)$ \\
\hline Education & $\begin{array}{c}2(0 \text { (No formal education })-3 \\
\text { (High School }))\end{array}$ \\
\hline $\begin{array}{l}\text { Experience (in } \\
\text { year) }\end{array}$ & $25(10-45)$ \\
\hline $\begin{array}{l}\text { Ship ownership } \\
\text { (person) }\end{array}$ & 12 \\
\hline
\end{tabular}

Most of the ship captains are in their productive age and they mostly graduated junior high school. They have been in the business for quite long time. Some of them have their own ship, while others are in a contract with owners of the ship under the system of profit sharing.

\subsection{Production Function}

Results of regression on stochastic frontier production function of purse seine capture are as follows:

Table 2. Production Function of Purse Seine

\begin{tabular}{lrrr}
\hline \multicolumn{1}{c}{ Attribute } & \multicolumn{1}{c}{$\boldsymbol{\beta}$} & t-ratio & Significance \\
\hline Intercept & -10.0 & $-11,44$ & 0,01 \\
Trip & 0.5 & 5,29 & 0,01 \\
Ship volume & -0.3 & $-0,75$ & - \\
Length of & & & \\
purse seine & 0.3 & 0,20 & - \\
FADs & 4.2 & 7,43 & 0,01 \\
Crew & 2.3 & 2,24 & 0,05 \\
\hline sigma- & & \\
squared & 0.073 & & \\
\hline Gamma & 0.999 & \\
\hline log likelihood function $=\mathbf{- 8 , 3 0 9 8 3 5}$ & \\
\hline LR test $=\mathbf{2 4 , 8 9 8 2 1 8}$ \\
restriction = 6 \\
chi square $(\mathbf{0 , 0 0 1 )}=\mathbf{2 1 , 6 6 6}$ \\
\hline
\end{tabular}

From these results, the value of LR test with $\ln \left\{\mathrm{L}\left(\mathrm{H}_{0}\right)\right\}$ is the log-likelihood function value in function of the null hypothesis (deterministic) and $\ln \left\{\mathrm{L}\left(\mathrm{H}_{1}\right)\right\}$ is the loglikelihood function value in function of the alternative hypothesis (stochastic). The value is positive and more than the value of $\chi^{2}(\mathrm{~J})$ belongs Kodde and Palm (1986), with $\mathrm{J}$ at 6 . Thus, it can be concluded that there are effects of inefficiencies in the production process that makes the stochastic production function describes the condition of production better than 
the deterministic function (there are no inefficiencies).

According to Table 2, all of the variables are good, i.e. trips and FADs, demonstrating positive parameter values at the significance level of 0.01 . FADs can simplify the process of capture by reducing search time of fishing ground and to simplify the process of casting purse seine nets because the fish is concentrated on FADs so stocking can be done without worrying that fish will be out of casting. Trip is a variable that indicates the intensity of catching fish. In theory, the variable is positive, as the result obtained in the variable is the same with the theory expressed by Pascoe (2003).

Crew variable, which indicates the number of fishermen per boat including captain needed as purse seine operators, has a positive and significant value at the level of significance of 0.05 . The existence of a positive value indicates the number of workers who operate thee purse seine ship on average still has not reached the optimum point, given a heavier workload on the east monsoon characterized by higher number of trips on the east season. Extra workers will have an impact on reducing the workload so fishing crews can recover more quickly from fatigue and they can endure more trips.

The variable of capacity base, i.e. the capacity (gross tonnage) and length of purse seine, has no significant effect on production. In the study site, the capacity base variable is indeed relatively homogeneous, so short capture ability is more affected by factors that illustrate the use of this capacity base variable.

In the variable of ship capacity, the result is not only insignificant but also negative. This shows high ship capacity is not needed in the research area with the current characteristics. It also answers the cause of INKAMINA vessel with a capacity of 30 GT as a support to fishermen in Pasongsongan is no longer used by fishermen. The results of the interviews with the captains, especially those who have ever used INKAMINA, show that the big ship uses more fuel yet the results are not different from the vessel under 20 GT in one-day trip system. The high ship also makes the process of moving the fish captured becomes difficult.

\subsection{Technical Efficiency}

Results of regression using FRONTIER 4.1 application show the average level of technical efficiency of fishing in Sumenep was 0.36 with the range of 0.15 to 0.99 . It shows that on average there is $64 \%$ of potential capacity that is not utilized due to inefficiency effects. It also means that there is excess capacity in capturing a number of outputs, as the potential current output is bigger (in accordance with the initial hypothesis). In addition to the human factor in the operation of the purse seine, Hiariey (2009) and Fauzi (2005) say that the technical inefficiency also happens because of competition in fishing.

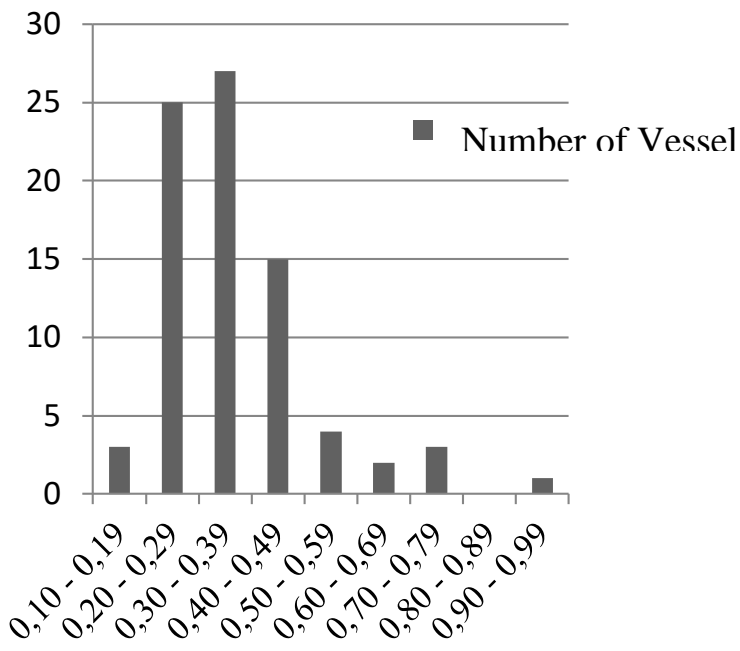

Figure 1. The Efficiency of Purse Seine Units

Due to the competition in the fishing, which essentially is a common natural resource of open access in the short term, makes fishermen go fishing more often without clear limit. Indefinite extra trips for each vessel will stimulate the occurrence of excess capacity or in other words the technical inefficiency. This is consistent with the regression results on purse seine production function in which the main factors that determines the amount of purse seine fishing capacity in Sumenep on a short-term (one season) are trips and FADs.

\subsection{Technical Inefficiencies Function}

The results of classical assumption tests show that the results of the regression pass normality test on the confidence level of 0.01 (Jarque-Berra). Heteroscedasticity test shows no significant value against residual. Autocorrelation shows a Durbin Watson value between du - 4 $\mathrm{du}$, and multicollinearity test shows VIF value of not more than 10 .

The negative sign on the experience shows that the more experience a captain has, the more capable the captain to manage production inputs at a more efficient level. Similar results have also been obtained in previous studies by Wetergrire 
and Ike (2015), Jamnia et al. (2013), Gbigbi and Tawo (2014), and Esmali (2006).

Table 3. Inefficiency Function of Purse Seine

\begin{tabular}{lccccc}
\hline Attribute & $\boldsymbol{\delta}$ & $\begin{array}{c}\text { z- } \\
\text { statis } \\
\text { tic }\end{array}$ & Sig & VIF & $\begin{array}{c}\text { Sig. } \\
\text { res }\end{array}$ \\
\hline Intercept & 0.3 & 5.8 & 0.01 & & \\
Age & 0.01 & 3.1 & 0.01 & 8.7 & 0.4 \\
Education & 0.09 & 4.4 & 0.01 & 1.4 & 0.5 \\
Experience & -0.01 & -3.1 & 0.01 & 7.6 & 0.6 \\
Ship & -0.06 & -1.9 & 0.1 & 1.0 & 0.9 \\
Ownership & & & & & \\
\hline
\end{tabular}

Likelihood Ratio = $41.31656(0.01)$

Jarque-Bera $=51.66357(0.01)$

Durbin-Watson $=1.979(\mathrm{dl}=1.39027 ; \mathrm{du}=$

$1.59531 ; \alpha=0.01$ )

Ship ownership variable also shows a negative sign, which indicates when the captain is also a ship owner, then the captain will give more effort during fishing trip. Similar results have also been obtained by previous research conducted by Esmali (2006).

A positive sign on formal educational (not in accordance with the initial hypothesis) means that the longer formal education positively affects the technical inefficiency or in other words, the production in a more inefficient level. Fishermen who have higher formal education have better social skills than those with little formal education. In general, the fisherman who have a higher level of education have a good relationship with the owner of the ship, and therefore even without experience and capabilities, they can be appointed as captain of the ship. In contrast, fishermen with lower levels of education, i.e. elementary school graduates or no formal education, have to put extra effort by taking certain levels of being a seafarer and assistant to be recommended as a captain. Therefore, fishermen with lower levels of formal education have more expertise in terms of purse seine fishing than the fishermen with higher levels of formal education.

A positive sign in the variable of age has also been found by previous researchers such as Wetergire and Ike (2015), Jamnia et al. (2013), and Esmali (2006). A positive sign in this age variable indicates that fishing using purse seine requires excellent body condition. This means that the older the age of the captain, the more inefficiency produced in fishing.

\section{Conclusion}

Based on SFA analysis, support in the form of purse seine vessels and purse seine fishing units with larger specification does not provide a significant effect toward fishing capacity of purse seine ships. To enhance the capacity of the unit with one-day trip system, due to close fishing grounds, the recommended support is on FADs, regulation on fishing trip or assistance related to the purpose of the fishing operation (trip), and the addition of crew on each unit of purse seine ships.

The results of the technical efficiency analysis show that fishing by the purse seine units is inefficient. These results suggest that the capacity used can still produce higher output levels.

The ability of the fishermen, especially the captain as the leader of the fishing operation, to gain efficient output (in accordance with the capacity of the units) is affected by experience and ownership of the vessel. Thus, the two become the factors that drive captains to produce efficiently. An increase in the age (older age) and formal education are the factors negatively correlated with the capture efficiency due to lack of trainings for prospective captains especially those with higher level of education. To improve the technical efficiency, the old age captains can be positioned as a trainer in the training program for prospective young captains with a high level of education.

\section{Reference}

Battese, G.E., dan T.J. Coelli. 1995. A Model of Technical Inefficiency Effects in a Stochastic Frontier Production Function for Panel Data. Empirical Economics, 20 : $325-332$.

Boesono, H., D.R. Setiawan, K.E. Prihantoko, B.B. Jayanto, dan A.R. Malala. 2016. Productivity Analysis of Mini Purse Seine in PPI Pulolampes Brebes, Central Java, Indonesia.

Coelli, T.J. 1996. A Guide to FRONTIER Version 4.1: A Computer Program for Stochastic Frontier Production and Cost Function Estimation. Working paper. University of New England. Australia.

Coelli, T.J., D.S.P. Rao, C.J. O’Donnell, dan G.E. Battese. 2005. An Introduction to 
Efficiency and Productivity Analysis. Springer. United States of America.

Dinas Perikanan dan Kelautan Povinsi Jawa Timur. 2014. Statistik Perikanan Tangkap Provinsi Jawa Timur Tahun 2014. Dinas Perikanan dan Kelautan Povinsi Jawa Timur. Surabaya.

Fauzi, A. 2010. Ekonomi Perikanan (Teori, Kebijakan, dan Pengelolaan). Gramedia Pustaka Utama. Jakarta.

Gbigbi, M.T., dan O.Taiwo. 2014. Technical Efficiency and Economic Return in Artisanal Fishery in the Niger-Delta, Nigeria. International Journal of Fisheries and Aquatic Studies, 2(1): $184-188$.

Hiariey, J. 2009. Status Eksploitasi Sumberdaya Ikan Pelagis Kecil di Perairan Maluku dan Kapasitas Penangkapannya. Disertasi. Sekolah Pascasarjana Institut Pertanian Bogor. Bogor.

Jamnia, A.R., S.M. Mazloumzadeh, dan A.A. Keikha. 2013. Estimate the Technical Efficiency of Fishing Vessels Operating in Chabahar Region Southern Iran. Journal of the Saudi Society of Agricultural Sciences, $14: 26-32$.

Kefi, O.S., E.M. Katiandagho, dan I.J. Paransa. 2013. Sukses Pengoperasian Pukat Cincin Sinar Lestari 04 Dengan Alat Bantu Rumpon yang Beroperasi Di Perairan Lolak Provinsi Sulawesi Sulawesi Utara. Jurnal Ilmu dan Teknologi Perikanan Tangkap, 1(3) : $69-75$.

Kodde, D.A., dan F.C. Palm. 1986. Wald Criteria for Jointly Testing Equality and Inequality Restriction. Econometrica, 54: 1243 1248.

Menteri Kelautan dan Perikanan Republik Indonesia. 2015. Peraturan Menteri Kelautan dan Perikanan Republik Indonesia Nomor 2/PERMEN-KP/2015 Tentang Larangan Penggunaan Alat Penangkapan Ikan Pukat Hela (Trawls) dan Pukat Tarik (Seine Nets) di Wilayah Pengelolaan Perikanan Negara Republik Indonesia. Jakarta.

Otieno, D.J., L. Hubbard, dan E. Ruto. 2014. Assessment of Technical Efficiency and Its Determinants in Beef Cattle Production in
Kenya. Journal of Development and Agricultural Economics, $6: 267-278$.

Pascoe, S., J.E. Kirkley, D. Greboval, dan C.J.M. Paul. 2003. Measuring and Assessing Capacity in Fisheries. Food and Agriculture Organization of The United Nation. Rome.

Rahman, R., Z. Zahid, S.S.M. Khairi, dan S.A.S. Hussin. 2016. Modeling Technical Efficiency of Inshore Fishery Using Data Envelopment Analysis. AIP Conference Proceedings, volume 1782 issue 1.

Scippacercola, S., dan L.D. Ambra. 2013. Estimating The Relative Efficiency of Secondary Schools by Stochastic Frontier Analysis. Procedia Economics and Finance, $17: 79-78$.

Tingley, D., S. Pascoe, dan Louisa Coglan. 2005. Factors Affecting Technical Efficiency in Fisheries : Stochastic Production Frontier Versus Data Envelopment Analysis Approaches. Fisheries Research, 73 : $363-$ 376.

Utomo, M.T.S., S.S. Djasmani, H. Saksono, dan Suadi. 2013. Analisis Usaha Purse Seine di Kecamatan Juwana Kabupaten Pati. Jurnal Perikanan (j. Fish. Sci.) XV, $2: 91-100$.

Wetegire, B.B, dan P.C. Ike, 2015. An Analysis of the Technical Efficiency of NonMotorized Small Scale Shrimp Fishers in the Coastal Area of Delta State Nigeria. Mediterranean Journal of Social Sciences, 6(1): $285-291$. 